\title{
The use of a land suitability model to predict where autumn-sown, determinate genotypes of the white lupin (Lupinus albus) might be grown in England and Wales
}

\author{
P. A. SIDDONS', R. J. A. JONES ${ }^{1}$, J. M. HOLLIS ${ }^{1}$, S. H. HALLETT ${ }^{1}$, C. HUYGHE \\ THE LATE J. M. DA Y ${ }^{2}$, T. SCOTT ${ }^{2}$ AND G. F. J. MILFORD \\ ${ }^{1}$ Computing and Information Systems, Soil Survey and Land Research Centre, Cranfield University, Silsoe \\ Campus, Silsoe, Bedford, Beds MK45 4DT, UK \\ ${ }^{2}$ Institute of Arable Crops Research, Rothamsted Experimental Station, Harpenden, \\ Herts ALS 2JQ, UK \\ ${ }^{3}$ INRA Centre de Recherches de Poitou-Charentes, Station d'Amélioration des Plantes Fourragères, 86600 \\ Lusignan, France
}

(Revised MS received 17 January 1994)

\section{SUMMAR Y}

A model was developed to assess the suitability of land in England and Wales for growing newly developed genotypes of autumn-sown determinate white lupins. The model used soil $\mathrm{pH}$, the number of degree-days accumulated for mainstem leaf production before the apical meristem of the mainstem became floral, and the number of machinery work days in autumn. Interactions between these three components were used to set thresholds to determine land suitability within $5 \times 5 \mathrm{~km}$ grid squares of the National Soil Map.

Of the potential 13.75 Mha of arable land in England and Wales, a total of 7.54 Mha are well or moderately suited to growing these lupin genotypes. This is equivalent to $c$. 2 Mha of land within the arable rotation each year. It was estimated that, because of low soil $\mathrm{pH}$, lupins would be the preferred legume on $0.3 \mathrm{Mha}$ out of this $2 \mathrm{Mha}$. The model was also used to assess the risk of soil acidification and nitrate leaching following mineralization of lupin residues. This exercise indicated that there was little risk of either on much of the land suited to lupins.

\section{INTRODUCTION}

The production of large surpluses of cereals and other arable crops within the EC during the past decade has stimulated the search for alternative combinable crops suited to the main arable areas of the UK. Research on oilseed rape and linseed has established their cultural needs, but there is still underproduction of protein and a need for additional grain legumes. Lupin seed contains $35-45 \%$ protein and $8-12 \%$ oil and is thus a temperate equivalent of the soya bean but, in the UK, it has more promise for its protein than for its oil. Lupins are a low-input crop of great potential within sustainable agricultural systems. They not only fix considerable quantities of atmospheric nitrogen, but their specialized, acid-secreting, proteoid roots can obtain both phosphorus and iron from insoluble sources within the soil that are not available to other crop species. A proportion of these nutrients may become available to following crops in the rotation.
The white lupin (Lupinus albus) originates from the Mediterranean area (Gladstones 1984) and there have been several attempts to introduce it into the UK during the past 3-4 decades (Williams 1979). These attempts failed, largely because the spring-sown, indeterminate genotypes that were then available had poor yield stability across seasons and locations and did not ripen consistently and sufficiently early to be commercially acceptable (Milford et al. 1993). However, new forms of $L$. albus have been developed recently that greatly enhance the crop's prospects in the UK. First, genotypes with sufficient cold hardiness and frost tolerance have been selected which allow lupins to be sown in autumn (Huyghe 1990). Although autumn sowing greatly enhanced the potential for yield and nitrogen fixation, it did not, of itself, guarantee early harvest (Milford et al. 1993). Second, genetically-determinate lines which produced only a mainstem plus one order of branches were selected from crosses involving the autumn-sown and epigonal genotypes (Huyghe 1990). These have better yield 
stability than indeterminate types and appear to be particularly well suited to UK conditions (Julier et al. 1993a). Experiments with one such line ( $\mathrm{CH} 304 / 70)$ in three very different, and far from ideal, growing producing high yields ( $4-5 \mathrm{t} / \mathrm{ha}$ of grain) and to ripen consistently in early September (G. F. J. Milford \& J. M. Day, unpublished). It is now undergoing commercial evaluation on a wider scale.

A number of factors determine the uptake and commercial success of a new arable crop. The more important of these are an identified commercial market for the produce, and the establishment of suitable agronomic and husbandry practices for the crop to be grown profitably. Also, it has to be demonstrated that the crop can be widely grown in the UK within the constraints imposed by land suitability and climate. Characterizing suitable edaphic and climatic regions requires extensive experimentation and experience, taking several years to achieve.

Provided that land types and regional climates can be specified and sufficient is known of crop responses to soil and weather factors, land suitability models offer an alternative and rapid means of producing maps showing suitable areas for a particular crop. The Soil Survey and Land Research Centre (SSLRC) have formulated land suitability models within the Land Information System (LandIS) for the major cereal and root crops that are currently grown in the UK (Jones \& Thomasson 1987; Thomasson \& Jones 1991). These models use appropriate manipulative software to access an extensive computerized database of such properties of the land as soil texture and structure, permeability and drainage status and accessibility or workability. This database is configured on $5 \times 5 \mathrm{~km}$ grid squares in which the dominant soil types from the National Soil Map (NSM) have been averaged. Also, the models access long-term weather records and so allow the suitability of the crop to be related to regional climate. This paper describes the development and application of such a model to assess the suitability of arable land in England and Wales for the autumn-sown, determinate white lupin breeding line, $\mathrm{CH} 304 / 70$. The databases have also been interrogated to indicate the scale of risk of soil acidification and nitrate leaching within the suited areas.

\section{THE LAND SUITABILITY MODEL}

\section{Plant/climate interactions}

Of the various factors in the land suitability models for cereals and root crops, that for droughtiness is not included in the model for lupins. This is because they are deep rooting. However, accumulated temperature is included because the plant's responses to temperature greatly influence its structure, even in seasons at Rothamsted showed it to be capable of

genetically determinate types. $\mathrm{CH} 304 / 70$ has a cold temperature requirement of $650^{\circ} \mathrm{C}$ days between 14 and $1{ }^{\circ} \mathrm{C}$ to become vernalized and for floral primordia to be initiated on the apical meristem of the mainstem (Huyghe 1992). The number of leaves and internodes on the mainstem is determined by the number of ${ }^{\circ} \mathrm{C}$ days above a base temperature of $3{ }^{\circ} \mathrm{C}$ that are accumulated before the apical meristem of the mainstem becomes floral. The thermal rate of leaf production is modified by the number of leaf primordia present in the seed and thus by seed size. Huyghe $(1992,1993)$ showed that leaf production can be described by the curvilinear regression equation:

$$
y=\left(5 \cdot 28+0 \cdot 0418 x+0 \cdot 00000986 x^{2}\right) z^{0 \cdot 12}
$$

where $y$ is the number of leaf primordia in the vegetative mainstem apex, $x$ is the accumulated temperature $>3{ }^{\circ} \mathrm{C}$ from sowing, and $z$ is the mean weight of the sown seed $(\mathrm{g} / \mathrm{seed})$. This relationship has been validated for $\mathrm{CH} 304 / 70$ grown in different seasons at a range of sites in France and the UK (C. Huyghe \& T. Scott, unpublished).

Julier \& Huyghe (1993) showed that in autumnsown, determinate genotypes such as $\mathrm{CH} 304 / 70$, the number of first-order branches and branch leaves, and hence the potential number of pods and seeds borne on these branches, was strongly determined by the number of mainstem leaves when these were varied by sowing on different dates at several locations in France. Experiments in the UK showed that at least 25 mainstem leaves are required to produce a potential maximum yield of $3.5 \mathrm{t} / \mathrm{ha}$, and 30-35 mainstem leaves to produce potential maximum yields of c. $5 \mathrm{t} /$ ha (J. M. Day \& G. F. J. Milford, unpublished). Using a value of $0.281 \mathrm{~g}$ for the mean seed weight $\mathrm{CH} 304 / 70$ (Julier et al. 1993b), the model (Eqn 1) predicted that 500 and $750^{\circ} \mathrm{C}$ days $>3{ }^{\circ} \mathrm{C}$ from sowing, respectively, must be accumulated before the apical meristem of the mainstem becomes vernalized sufficiently to produce these leaf numbers. The production of $>35$ mainstem leaves results in a tall crop that would need a growth regulator applied in spring to prevent loss of yield through lodging.

For each location there is a limited period in the autumn when sowing must occur in order to ensure successful establishment and the plant structure necessary to produce an economic yield. This period is defined by (i) the time taken to accumulate $650^{\circ} \mathrm{C}$ days between 14 and $1{ }^{\circ} \mathrm{C}$ required for the mainstem to become floral $\left(\Sigma T_{1}\right)$, and (ii) the number of ${ }^{\circ} \mathrm{C}$ days $>3{ }^{\circ} \mathrm{C}\left(\Sigma T_{3}\right)$ that can be accumulated during this time. These were calculated from the daily records for the years $1961-80$ from 87 meteorological stations in England and Wales using the ATGEN suite of programs (Hallett \& Jones 1993). Strictly, for use in the lupin land suitability model, $\Sigma T_{1}$ should be calculated by accumulating temperature only when the daily mean is between 1 and $14{ }^{\circ} \mathrm{C}$, but ATGEN does not currently Downloaded from https://www.cambridge.org/core. BBSRC, on 12 Apr 2021 at 17:19:51, subject to the Cambridge Core terms of use, available at https://www.cambridge.org/core/terms. https://doi.org/10.1017/S0021859600068465 
Table I. Land categorization tables to determine land suitability for the cultivation of white lupins combining decisions based on (a) soil pH of the dominant soil series and adjustment through cropping condition, $(b)$ the potential yield category determined from adjusted soil $\mathrm{pH}$ and accumulated temperature, and (c) from yield category and autumn machinery work days

\begin{tabular}{|c|c|c|c|c|c|}
\hline \multirow{2}{*}{$\begin{array}{l}\text { (a) } \\
\text { Cereals cropping* }\end{array}$} & \multicolumn{5}{|c|}{$\mathrm{pH}$ value for dominant soil series } \\
\hline & \multicolumn{2}{|c|}{$\begin{array}{l}<4.5 \\
\text { Unsuited }\end{array}$} & $\begin{array}{l}4.5 \text { to }<7.0 \\
\text { Well suited }\end{array}$ & $\begin{array}{l}7.0 \text { to }<7.5 \\
\text { Moderate }\end{array}$ & $\begin{array}{l}>7 \cdot 5 \\
\text { Unsuited }\end{array}$ \\
\hline $\begin{array}{l}<10 \% \\
>10 \%\end{array}$ & \multirow[t]{3}{*}{$\begin{array}{l}\text { Unsui } \\
\text { Well } s\end{array}$} & \multicolumn{2}{|c|}{$\begin{array}{l}\text { Well suited } \\
\text { Well suited }\end{array}$} & $\begin{array}{l}\text { Moderate } \\
\text { Moderate }\end{array}$ & $\begin{array}{l}\text { Unsuited } \\
\text { Unsuited }\end{array}$ \\
\hline (b) & & \multicolumn{4}{|c|}{ Adjusted soil pH category } \\
\hline Temperature $\left(\Sigma T_{3}\right)$ & & \multicolumn{2}{|c|}{ Well suited } & Moderate & Unsuited \\
\hline \multicolumn{2}{|l|}{$\begin{array}{l}<400, \text { unsuited } \\
400 \text { to }<500, \text { marginal } \\
500 \text { to }<750, \text { well suited } \\
>750, \text { moderate }\end{array}$} & \multicolumn{2}{|c|}{$\begin{array}{l}\text { Unsuited } \\
\text { Marginal } \\
\text { Good } \\
\text { Moderate }\end{array}$} & $\begin{array}{l}\text { Unsuited } \\
\text { Marginal } \\
\text { Moderate } \\
\text { Moderate }\end{array}$ & $\begin{array}{l}\text { Unsuited } \\
\text { Unsuited } \\
\text { Unsuited } \\
\text { Unsuited }\end{array}$ \\
\hline \multicolumn{2}{|l|}{$(c)$} & \multicolumn{4}{|c|}{ Potential yield category using soil $\mathrm{pH}$ and $\Sigma T_{3}$} \\
\hline \multicolumn{2}{|c|}{ Autumn machinery work days } & Unsuited & Marginal & Moderate & Good \\
\hline \multicolumn{2}{|l|}{$\begin{array}{l}<1 \text {, unsuited } \\
1 \text { to }<20 \text {, marginal } \\
20 \text { to }<50 \text {, moderate } \\
>50, \text { well suited }\end{array}$} & $\begin{array}{l}\text { Unsuited } \\
\text { Unsuited } \\
\text { Unsuited } \\
\text { Unsuited }\end{array}$ & $\begin{array}{l}\text { Unsuited } \\
\text { Unsuited } \\
\text { Marginal } \\
\text { Marginal }\end{array}$ & $\begin{array}{l}\text { Unsuited } \\
\text { Marginal } \\
\text { Moderate } \\
\text { Moderate }\end{array}$ & $\begin{array}{l}\text { Unsuited } \\
\text { Marginal } \\
\text { Moderate } \\
\text { Well suited }\end{array}$ \\
\hline
\end{tabular}

* From 1988 Agricultural Census.

allow an upper limit to be specified. This did not matter in practice because mean daily temperatures in England and Wales rarely, if ever, rise above $14^{\circ} \mathrm{C}$ between the beginning of September and the end of March.

First, $\Sigma T_{1}$ was calculated from 1 September and the date noted on which it reached $650^{\circ} \mathrm{C}$ days; $\Sigma T_{3}$ was then calculated for this same period. The $\Sigma T_{3}$ data were then interpolated on to the NSM $5 \times 5 \mathrm{~km}$ grid across England and Wales using the interpolation procedure of Jones \& Thomasson (1985). The coefficients of the algorithm:

\section{$\Sigma T_{3}=570.52535-0.1221796^{*} A L T-$ $0.0000032 * E A S T-0.0004089^{*}$ NORTH}

based on altitude $(A L T)$, easting $(E A S T)$ and northing (NORTH) were obtained from a multiple regression analysis using the KWIKSTAT (V2.0) statistical package $\left(R^{2}=0.824\right)$.

If $\Sigma T_{3}$ was between 500 and $700^{\circ} \mathrm{C}$ days, sufficient to produce 25-35 leaves, the location was considered to be potentially climatically well suited to produce acceptable yields. If $\Sigma T_{3}$ was between 400 and $500^{\circ} \mathrm{C}$ days, the location was considered to be of marginal yield potential; if $\Sigma T_{3}$ was $>750^{\circ} \mathrm{C}$ days, and there was a subsequent risk of crop lodging, the location was considered to be of moderate yield potential.

\section{Soil $p H$}

Soils in England and Wales have a wide range in $\mathrm{pH}$, to which lupins are sensitive. The $\mathrm{pH}$ sensitivity of $\mathrm{CH} 304 / 70$ has been characterized using long-term plots at Rothamsted with well-established soil $\mathrm{pH}$ (J. M. Day \& I. Shield, unpublished). Lupins, like many other species, do not readily tolerate highly acid conditions $<\mathrm{pH} 4.5$, probably because of the accumulation of toxic concentrations of aluminium. However, they also do not tolerate calcareous soils with $\mathrm{pH}>7.5$ because of their acid-secreting mechanism for acquiring phosphorus and iron. Nodulation for nitrogen fixation requires effective strains of Bradyrhizobium lupini. Most UK soils $<\mathrm{pH} 6.5$ contain sufficient rhizobia for effective nodulation, but between $\mathrm{pH} 6.5$ and 7.5 inoculation is essential and inoculants and inoculant technology are available.

For our land suitability model for lupins, soils within the $\mathrm{pH}$ range $4 \cdot 5-7.0$ (measured in water with a soil: water ratio of $1: 2.5$ ) were considered to be well suited, those between $\mathrm{pH} 7.0$ and 7.5 moderately suited, and those $<\mathrm{pH} 4.5$ and $>\mathrm{pH} 7.5$ unsuited. Each $5 \times 5 \mathrm{~km}$ grid square in England and Wales can be assigned to one of these soil $\mathrm{pH}$ suitability classes according to the estimated $\mathrm{pH}$ range of its dominant 
soil series as interpolated from a soil buffering capacity dataset held within LandIS. Where the $\mathrm{pH}$ of the dominant soil series was estimated to be $<4.5$, a $5 \times 5 \mathrm{~km}$ resolution cropping database generated from the 1988 data of the Parish Agricultural Census of the Ministry of Agriculture, Fisheries and Food (Edinburgh University Data Library) was used to provide information on cereal cropping. If cereal cropping was practised on $>250$ ha per grid square (i.e. $>10 \%$ of the area) then the $\mathrm{pH}$ suitability category was upgraded to well suited (see Table 1). This was because, in such areas, farmers are advised to add chalk regularly to maintain soil $\mathrm{pH}$ at $c .6 \cdot 5$.

\section{Autumn machinery working days}

The period during which soil moisture is at field capacity or remains at zero deficit can be used as a measure of the accessibility of land to machinery (Jones 1985). Allowance needs to be made for soil properties because the cultivation of well-drained, coarse-textured soils is often possible without harmful effects whereas, under the same climate, clayey or otherwise slowly permeable soils are often impassable. The workability scheme devised by Thomasson (1982) combines soil field capacity data with soil structure, permeability and potential rainfall to calculate the machinery working days (MWD) suitable for landwork.

MWDs for autumn have been calculated for each $5 \times 5 \mathrm{~km}$ grid square across England and Wales using the average climatic data available in LandIS (Thomasson \& Jones 1989). It is the number of days between 1 September and the return to field capacity, adjusted with a soil assessment weighting based on topsoil texture, subsoil porosity and soil water regime (Jones \& Thomasson 1985, 1987). A location with 50 or more MWDs was considered well suited to growing lupins, one with 20-50 MWDs moderately suited, one with 1-20 MWDs marginally suited, and one with $<1$ working day unsuited.

\section{The land suitability model for lupins}

This land suitability model was arranged as a cascading series of decision tables which are shown in Table 1. Locations were initially categorized on the basis of soil pH (Table $1 a$ ), then on the suitability of the local climate for growth and yield (Table $1 b$ ), and finally on land workability (Table $1 c$ ) to produce the overall suitability class for each of $5 \times 5 \mathrm{~km}$ grid squares of England and Wales. Urban areas, lakes and grid squares with missing data were not classified. More detailed definitions of the suitability of land within the various classes that also relates them to the required agronomy have been given by Jones \& Thomasson (1987).

\section{Modifications to the land suitability model}

The land suitability classes identified by the basic model were further subdivided according to the susceptibility of the soils to acidification if they did not receive regular applications of lime, or to the leaching of nitrate into underlying ground waters.

\section{Susceptibility to acidification}

All the soil series on the legend of the 1:250000 scale National Soil Maps have been classified according to their susceptibility to acidification without regular liming. The classification assumes that the soil is currently under agricultural use with its $\mathrm{pH}$ maintained at or near neutral values, and assesses its susceptibility to relatively rapid acidification if no lime is applied to neutralize the potential acidifying effects of crops within the rotation. Classification is based on criteria which broadly differentiate soils according to their permeability and buffering capacity. For example, all soils with characteristics indicating they are permeable throughout, retain a relatively small proportion of excess water against drainage, and also have a low buffering capacity, are assigned to the very susceptible class. An additional class not under agriculture was created to cater for all upland soils that are not normally under arable or improved grassland farming systems.

\section{Nitrate leaching risk}

The leaching risk for each soil series has already been determined to estimate the potential nitrate leaching losses from agricultural land (Jones et al. 1989; Jones \& Thomasson 1990). Within LandIS, each $5 \times 5 \mathrm{~km}$ grid square was assigned to a leaching risk class according to its dominant soil series (P. J. Loveland, personal communication). For the present study, the four leaching classes defined by Jones et al. (1989) were reduced to three by incorporating the extreme high risk with the high risk class, the resulting combination being termed 'high risk'.

\section{RESULTS AND DISCUSSION}

The map of the suitability of land in England and Wales for growing autumn-sown, determinate genotypes of the white lupin is shown in Fig. 1, and the areas and proportions of the total area within each of the suitability classes are given in Table $2 a$. Over $3.6 \mathrm{Mha}$ of the agricultural land $(24 \%$ of the total area) is well suited to the cultivation of these new genotypes of lupin, and a further 3.9 Mha ( $26 \%$ of the total) moderately suited (Table $2 a$ ). Both of these classes of land were well distributed throughout the two countries. Upland areas in Wales and the northand south-west of England were not suited, some because of highly acid soils, but the majority because

altitude limited machinery work days or made the Downloaded from https://www.cambridge.org/core. BBSRC, on 12 Apr 2021 at 17:19:51, subject to the Cambridge Core terms of use, available at 


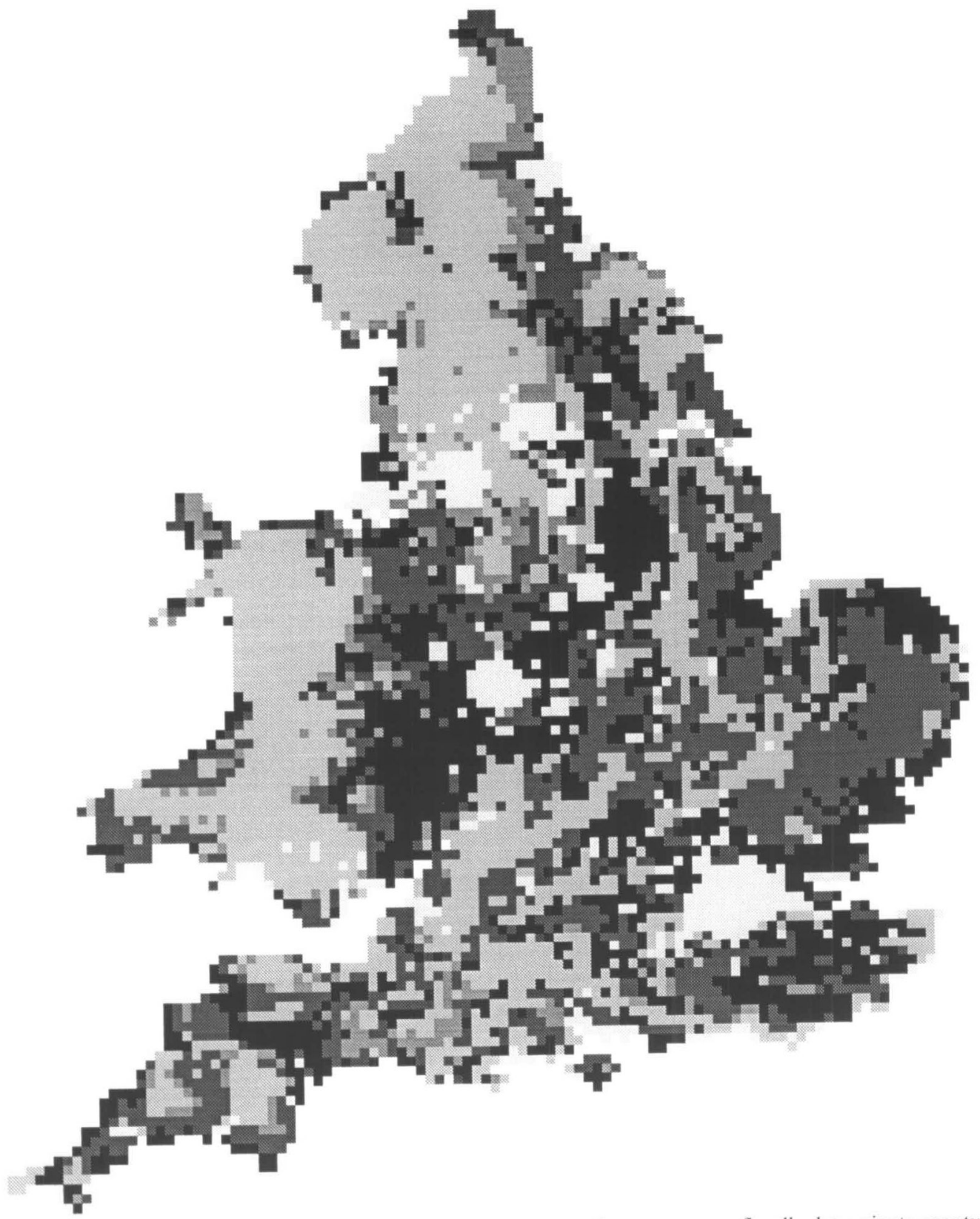

Fig. 1. The suitability of land in England and Wales for the cultivation of autumn-sown, florally determinate genotypes of



areas climatically unsuited to lupins. The other unsuitable locations were clustered along the main chalk ridges of the north and south downs, the Chilterns and those through East Anglia, and along the limestone escarpments of the Mendips and the Lincolnshire and Yorkshire wolds (Fig. 1). High soil $\mathrm{pH}$ was the main limiting factor in these areas.

The land suitability classes identified by the basic model were further subdivided for the purpose of environmental audits. Because lupins acidify the rhizosphere as part of their natural mechanism of nutrient acquisition there is concern that too frequent growing of lupins might lead to excessive acidification of the soils within the favoured $\mathrm{pH}$ range. The risk of this appeared to be slight. Of the $7.5 \mathrm{Mha}$ of arable land identified as being well or moderately suited to 
Table 2. The suitability of land in England and Wales for growing autumn-sown, determinate genotypes of the white lupin and categorization of that land according to susceptibility to soil acidification and the risk of nitrate leaching. All areas in millions of hectares

\begin{tabular}{|c|c|c|c|c|c|c|}
\hline & \multicolumn{5}{|c|}{ Classification* } & \multirow[b]{2}{*}{ Total } \\
\hline & $\begin{array}{c}\text { Well } \\
\text { suited }\end{array}$ & $\begin{array}{c}\text { Moderately } \\
\text { suited }\end{array}$ & $\begin{array}{l}\text { Marginally } \\
\text { suited }\end{array}$ & Unsuited & Unclassified & \\
\hline \multicolumn{7}{|c|}{ (a) Land suited to the cultivation of lupins } \\
\hline Area & 3.633 & 3.905 & 0.945 & $5 \cdot 268$ & $1 \cdot 193$ & $14 \cdot 944$ \\
\hline$\%$ of total & $24 \cdot 3$ & $26 \cdot 1$ & $6 \cdot 3$ & $35 \cdot 3$ & $8 \cdot 0$ & \\
\hline \multicolumn{7}{|c|}{ (b) Area susceptible to soil acidification } \\
\hline Very susceptible & $0 \cdot 715$ & 0.097 & 0.013 & & & 0.825 \\
\hline Moderately susceptible & 1.018 & 0.683 & $0 \cdot 188$ & & & 1.889 \\
\hline Not susceptible & 1.848 & $3 \cdot 123$ & 0.738 & & & $5 \cdot 709$ \\
\hline Not under agriculture & 0.053 & $0 \cdot 003$ & $0 \cdot 008$ & & & $0 \cdot 064$ \\
\hline \multicolumn{7}{|c|}{ (c) Area at risk of nitrate leaching } \\
\hline High risk & $2 \cdot 223$ & $1 \cdot 048$ & 0.220 & & & $3.49 !$ \\
\hline Moderate risk & $1 \cdot 700$ & 1.650 & 0.010 & & & $3 \cdot 360$ \\
\hline Low risk & $1 \cdot 240$ & $2 \cdot 639$ & 0.715 & & & $4 \cdot 648$ \\
\hline
\end{tabular}

* SSLRC Cranfield (1993).

growing lupins, $5.0 \mathrm{Mha}$ was not liable to acidify quickly as a result of the acid excretion from lupin roots, 1.7 Mha was moderately susceptible, and only 0.8 Mha was very susceptible (Table $2 b$ ). The modelling exercise also showed that there was a high risk of nitrate leaching on 3.3 Mha of the land identified as well or moderately suited for lupins and a low risk on 3.9 Mha (Table $2 c$ ). Lupins are unlikely to be grown too frequently on soils that are susceptible to excessive leaching of nitrate but they might be an ideal option because they do not require nitrogen fertilizer. Initial measurements indicated that the autumn-sown, determinate genotypes accumulated c. $350 \mathrm{~N} /$ ha, of which only $50 \mathrm{~kg} / \mathrm{ha}$ was returned to the soil in the straw, pod-wall and root residues. The residual nitrogen is little more than that from a conventional cereal, and much less than those from oilseed rape, sugarbeet, peas and beans (J. M. Day, G. F. J. Milford \& P. Roemer, unpublished).

The major shortcomings of lupins as a crop for the UK (i.e. late harvest and instability of yield) now appear to have been overcome by the selection of new autumn-sown, florally determinate genotypes such as $\mathrm{CH} 304 / 70$. When grown at Rothamsted in three contrasting and far from ideal seasons, this genotype yielded between 3.5 and $5.0 t$ of grain/ha and harvest was in early to mid-September (G. F. J. Milford \& J. M. Day, unpublished). These yields are only attained if crops are sown early, because the number of mainstem leaves, plant height and the number and size of pod-bearing branches are greatly decreased by the rate of post-sowing, cold-temperature vernalization (Julier \& Huyghe 1993). The pronounced genotype $\times$ environment interaction needs to be con- date when determining the suitability of land within the different regions of England and Wales for the cultivation of lupins. For this reason, the new genotype's vernalization behaviour was one of the main criteria used in the land suitability model.

Land suitability models have predominantly been used to examine the scope for existing crops (Jones \& Thomasson 1987; Thomasson \& Jones 1991). In the present study, one such model has been used for the first time to predict the potential acreage for a novel crop that is not yet widely grown. There are $13.7 \mathrm{Mha}$ of arable land in England and Wales of which 7.5 Mha are well or moderately suited for growing lupins (Table 2). Assuming that farmers use a 6 or 7 year rotation to accommodate set-aside requirements and a legume break-crop once per rotation, there are c. 2 Mha available for the cultivation of peas, beans and lupins per year. The model predicted that about half of this area would be suited to the cultivation of lupins (Table 2) and that the land was reasonably well distributed throughout the two countries (Fig. 1). The main areas not suited to lupins were those of soil $\mathrm{pH}$ $>7.5$ (i.e. chalk and limestone escarpments and calcareous sandstones), which are areas where peas and beans are predominantly grown.

The factors that determine which legume crop farmers choose to grow include the potential market and price, cost of production and profitability, shortterm effects on subsequent crops and long-term environmental impact. The European Community is a net importer of protein. The UK alone imports $0.45 \mathrm{mt}$ of soyabeans, $1.20 \mathrm{mt}$ of soyabean meal and cake, and $0.11 \mathrm{mt}$ of groundnut meal per annum, mainly for animal feed (Anon. 1993). As UKproduced lupin seed contains $35-40 \%$ protein and sidered in relation to regional weather and sowing Downloaded from https://www.cambridge.org/core. BBSRC, on 12 Apr 2021 at 17:19:51, subject to the Cambridge Core terms of use, available at https://www.cambridge.org/core/terms. https://doi.org/10.1017/S0021859600068465 
$10 \%$ oil, their main market would be as a substitute for these imports; they would not necessarily decrease the current market for peas and beans. Initial comparisons indicate that the cost of production and gross margin for lupins are similar to those for winter beans and peas (1. Shield, personal communication). Crop choice will therefore primarily depend on the growers' preference for a winter- or spring-sown crop, difficulties experienced in harvesting peas, or the particular suitability of the land. Since lime subsidies were withdrawn, the ADAS Representative Soil Sampling Scheme (1983-88) has shown that $14 \%$ of arable fields in England and Wales now have a $\mathrm{pH}$ $<6.5$ (Palmer 1993). This implies that there is a substantial area of arable land in England and Wales that is not suited to peas and beans because it is too acid, and where lupins would be a preferred choice. The exact proportion of land with a soil $\mathrm{pH}$ in the range $4.5-6 \cdot 5$ as opposed to $6 \cdot 5-7.5$ is now the subject of further study.

This study was commissioned by the Chief Scientist's Group of the Ministry of Agriculture, Fisheries and Food. The authors thank colleagues at the SSLRC for their contributions to the establishment of databases, software programming and computer services in running the model, and those at IACR Rothamsted for helpful information and advice.

\section{REFERENCES}

ANON. (1993). Trade and production statistics. Oilworld, February 1993.

Gladstones, J. S. (1984). Present situation and potential of Mediterranean/African lupins for crop production. In Proceedings of the 3rd International Lupin Conference, pp. 18-37. La Rochelle, France: International Lupin Association.

Hallett, S. H. \& Jones, R. J. A. (1993). Compilation of an accumulated temperature database for use in an environmental information system. Agricultural and Forest Methodology 63, 21-34.

HUYGHE, C. (1990). White lupin architecture: genetic variability and agronomic consequences. In Proceedings of the 6th International Lupin Conference (Ed. D. von Bauer), pp. 241-254. Temuco-Pucon, Chile: International Lupin Association.

Huyghe, C. (1992). Lupin architectural models. In Proceedings of a Workshop on Physiological and Genetic Approaches to Adapting the Architecture of the White Lupin (Lupinus albus) for Successful Cultivation in Different Regions of Europe, pp. 1-5. Lusignan: INRA.

HuYGHE, C. (1993). Growth of white lupin seedlings during the rosette stage as affected by seed size. Agronomie 13, 145-153.

Jones, R. J. A. (1985). The Soil Survey's field capacity - an aid to assessing soil wetness. Soil and Land Evaluation 5 , $1-12$.

Jones, R. J. A. \& Thomasson, A. J. (1985). An agroclimatic databank for England and Wales. Soil Survey Technical Monograph No. 16.

Jones, R. J. A. \& Thomasson, A. J. (1987). Land suitability classification for temperate arable crops. In Quantified Land Evaluation Procedures (Eds K. J. Beek, P. A. Burrough \& D. E. McCormack), pp. 29-35. Enschede: ITC Publication.

Jones, R. J. A. \& Thomasson, A. J. (1990). Mapping potential nitrate leaching losses from agricultural land in the UK. In Nitrates and Pollution (Eds P. J. C. Hamer \& P. Leeds-Harrison), pp. 35-46. Cranfield: UK Irrigation Technical Monograph No. 3.

Jones, R. J. A., Thomasson, A. J., Robson, J. D. \& Carter,
A. D. (1989). The distribution of nitrate leaching losses from agricultural land in the UK based on computerised soil and climatic data. In Agriculture: Computerization of Land Use Data (Eds R. J. A. Jones \& B. Biagi), pp. 85-96. Luxembourg: Commission of the European Communities. Julier, B. \& HuYGHE, C. (1993). Description and model of the architecture of four determinate genotypes of autumnsown white lupin (Lupinus albus) as influenced by location, sowing date and density. Annals of Botany 72, 493-501.

Julier, B., Huyghe, C., Papineau, J., Milford, G. F. J., Day, J. M., Billot, C. \& Mangin, P. (1993a). Seed yield and yield stability of determinate and indeterminate autumn-sown white lupins (Lupinus albus) grown at different locations in France and the UK. Journal of Agricultural Science, Cambridge 121, 177-186.

Julier, B., Huyghe, C. \& Papineau, J. (1993b). Dry matter and nitrogen accumulation and seed yield in determinate, autumn-sown white lupins (Lupinus albus L.). Agronomie $13,877-888$.

Milford, G. F. J., Day, J. M., Huyghe, C. \& Julier, B. (1993). Floral determinacy in autumn-sown white lupins (Lupinus albus): the development of varieties for cooler European climates. In Physiology of Varieties: Aspects of Applied Biology 34 (Eds E. White, P.S. Kettlewell, M. A. Parry \& R. P. Ellis), pp. 89-97. Wellesbourne: Association of Applied Biologists.

Palmer, R. (1993). Is it time for lime? Crops 11 (15), 30.

Thomasson, A. J. (1982). Soil and climatic aspects of workability and trafficability. In Proceedings of the $9 \mathrm{th}$ Conference of the International Soil Tillage Research Organisation, Osijek, Yugoslavia, pp. 551-557.

Thomasson, A. J. \& Jones, R. J. A. (1989). Computer mapping of soil trafficability in the UK. In Agriculture: Computerization of Land Use Data (Eds R. J. A. Jones \& B. Biagi), pp. 97-109. Luxembourg: Commission of the European Communities.

Thomasson, A. J. \& Jones, R. J. A. (1991). An empirical approach to crop modelling and the assessment of land productivity. Agricultural Systems 37, 351-367.

Williams, W. (1979). Studies on the development of lupins for oil and protein. Euphytica 28, 481-488. 